\title{
Digestible tryptophan levels for male broilers in pre-starter and starter diets
}

\author{
Níveis de triptofano digestível para frangos de corte machos nas \\ dietas pré-inicial e inicial
}

\author{
Bruno Samuel Borges ${ }^{1 *}$; Romão da Cunha Nunes ${ }^{2}$; Jose Henrique Stringhni²; \\ Alessandra Gimenez Mascarenhas²; Heloísa Helena de Carvalho Mello²; \\ Julyana Machado da Silva Martins ${ }^{3}$; Raiana Almeida Noleto ${ }^{3}$; \\ Maryelle Durães de Oliveira ${ }^{3}$
}

\begin{abstract}
The objective was to determine the digestible tryptophan requirements for male broilers in pre-starter and starter phases. Two experiments using 400 Cobb broilers were performed 200 males in the first experiment for the pre-starter phase (one to seven days old), and 200 males in the second experiment for the starter phase (eight to 21 days old). Chicks were housed in batter boxes made of galvanized steel as an experimental shed. The experiments were performed in a completely randomized design, with four treatments and five replicates, with ten birds each. In both experiments, the tryptophan requirement was determined using diets with different levels of digestible tryptophan. A tryptophan-deficient diet was formulated, as a basal diet, which was supplemented with increased levels of L-tryptophan in order to achieve the desirable digestible tryptophan levels. Treatments consisted of $0.209 \%$ (basal diet); $0.223 \% ; 0.235 \%$ and $0.248 \%$ digestible tryptophan for the pre-starter phase (experiment 1 ) and $0.187 \%$ (basal diet); $0.200 \%, 0.211 \%$ and $0.223 \%$ digestible tryptophan for the starter phase (experiment 2). We evaluated feed intake, weight gain and feed conversion, as well as the metabolizability of feed nutrients. The performance and metabolic data were subjected to analysis of variance, and estimates of digestible tryptophan levels were made through polynomial regression models at $5 \%$ probability. There was no significant difference between the digestible tryptophan levels in the diet over performance and digestibility in both treatments. It is possible to conclude that the basal diet with $0.209 \%$ digestible tryptophan for the pre-starter phase and $0.187 \%$ for the starter phase, at a tryptophan: lysine ratio of $16 \%$, as sufficient to meet the broilers requirements.
\end{abstract}

Key words: Animal nutrition. Chickens. Digestible amino acid. Digestibility. Performance.

\section{Resumo}

Objetivou-se determinar as exigências de triptofano digestível para frangos de corte machos nas fases pré-inicial e inicial. Foram realizados dois experimentos utilizando 400 frangos de corte da linhagem Cobb, sendo o experimento 1 com 200 machos para a fase pré-inicial (um a sete dias de idade), e o

\footnotetext{
${ }^{1}$ M.e em Ciência Animal, Escola de Medicina Veterinária e Zootecnia, EVZ, Universidade Federal de Goiás, UFG, Goiânia, GO, Brasil. E-mail: brunozootecnia22@hotmail.com

2 Profs., Pós-Graduação em Zootecnia, EVZ/UFG, Goiânia, GO, Brasil. E-mail: romaocnunes@hotmail.com; jhstring@uol.com. br; alegimenez09@hotmail.com; heloisamello@gmail.com

${ }^{3}$ Discentes do Curso de Doutorado em Zootecnia, EVZ/UFG, Goiânia, GO, Brasil. E-mail: julyanamachado_zoo@hotmail.com; raianazoo@hotmail.com; mary_zoo@hotmail.com

* Author for correspondence
} 
experimento 2 com 200 machos para a fase inicial (oito a 21 dias de idade), alojados em baterias, contendo gaiolas de arame galvanizado, em um galpão experimental. Os experimentos foram realizados em delineamento inteiramente casualizado, divididos em quatro tratamentos, com cinco repetições e dez aves por repetição, sendo que cada repetição compreendia uma unidade experimental. Em ambos os experimentos a exigência de triptofano foi determinada utilizando dietas com diferentes níveis de triptofano digestível. Foi formulada uma ração com deficiência em triptofano, considerada a ração basal, a qual foi suplementada com L-triptofano em substituição ao material inerte com o objetivo de alcançar os níveis de triptofano digestível desejáveis. Os tratamentos consistiram em $0.209 \%$ (ração basal); $0.223 \% ; 0.235 \%$ e $0.248 \%$ de triptofano digestível para a fase pré-inicial (experimento 1 ) e $0.187 \%$ (ração basal); $0.200 \% ; 0.211 \%$ e $0.223 \%$ de triptofano digestível para a fase inicial (experimento 2). Foram avaliados o consumo de ração, o ganho de peso e a conversão alimentar, bem como foi realizada a avaliação da digestibilidade dos nutrientes das rações. Os dados de desempenho e metabolização dos nutrientes da ração foram submetidos à análise de variância, e as estimativas dos níveis de triptofano digestível foram efetuadas através dos modelos de regressão polinomial, em nível de $5 \%$ de probabilidade. Não houve diferença significativa entre os níveis de triptofano digestíveis da ração sobre o desempenho e digestibilidade das dietas em ambas as fases. É possível concluir que a dieta basal com $0.209 \%$ de triptofano digestível para a fase pré-inicial e $0.187 \%$ para a fase inicial, a uma relação triptofano:lisina de 16\%, demonstrou-se suficiente para atender as exigências de frangos de corte machos.

Palavras-chave: Nutrição animal. Aves. Aminoácido digestível. Digestibilidade. Desempenho.

\section{Introduction}

For many years, the formulation of chicken feedwas based on the concept of crude protein, resulting in amino acid content above that required by animals (SILVA et al., 2010). As the production of synthetic amino acids has increased in the world, diets have started to be formulated with lower protein levels and increased amino acid levels according to broilers requirements. There are many studies in which diets containing reduced crude protein levels and supplemented with industrial amino acids inclusion (AFTAB et al., 2006; CORZO et al., 2010; DOZIER et al., 2011). There is significant interest in amino acids such as lysine, methionine, threonine, valine, arginine, isoleucine and tryptophan when the concept of ideal protein is used for poultry.

Tryptophan is known as the amino acid with the lowest dietary concentration, representing about $1 \%$ in animal proteins and $1.4 \%$ in vegetable proteins. Because of the presence of an aromatic ring in its chemical structure, it is able to participate in the formation of many organic compounds in the animal body. This fact can be emphasized because it is an essential amino acid not synthesized or synthesized in insufficient concentrationto meet the metabolic requirements. Besides being a structural component of all proteins, it is a precursor for the synthesis of two hormones, serotonin and melatonin (ELSLAMONEY et al., 2010; ROSSI; TIRAPEGUI, 2004).

Tryptophan tends to be a limiting amino acid in poultry diets, as the crude protein of the feed decreases and industrial L-tryptophan in is available to be used as a supplement in poultry feed at a reasonable price. This amino acid isconsidered more when using diets containing a large amount of meat meal or poultry by-products (KIDD; HACKENHAAR, 2006).

The requirements for chickens can range from $0.16 \%$ to $0.19 \%$ of digestible tryptophan (BORGES et al., 2002; CAMPOS et al., 2012; DUARTE et al., 2012; ROSTAGNO et al., 2005, 2011; SIQUEIRA et al., 2011; TAKEARA et al., 2010; VALÉRIO et al., 2003).

Therefore, this research aimed to determine the nutritional requirements of digestible tryptophanfor male broilers in the pre-starter and starter phases. 


\section{Material and Methods}

Two experiments were carried outat the Poultry Research Station of the Department of Animal Science, School of Veterinary and Animal Science of UFG (Federal University of Goiás) Campus Samambaia, in Goiania, state of Goiás, Brazil. The experiments took place in the period from December 23, 2013 to January 13, 2014.

Chicks were housed in heated batteries made of galvanized steel with 10 boxes of $0.50 \mathrm{~m} \times 0.40 \mathrm{~m}$ x $0.40 \mathrm{~m}$, excreta collection trays, and linear feeders and drinkers. The boxes were located in a facility with a clay tile roof, concrete floors, screened walls and side curtains. Heating of the birds was done by incandescent lamps of $60 \mathrm{~W}$ per box based on the thermometer positioned at the height of the birds, and according to their behavior.

A total of 400 Cobb male chicks were used. In experiment 1 there were 200 males for the prestarter phase (one to seven days old), and the experiment 2 there were 200 males for the starter phase (eight to 21 days of age). The experiments were conducted in a completely randomized design with four treatments, five replicates and ten birds per repetition, with eachrepetition as an experimental unit.

Experimental diets containing different levels of digestible tryptophan were formulated based on Rostagno et al. (2011) recommendations. A tryptophan-deficient diet was formulated, considered as a basal diet, which was supplemented with L-tryptophan to replace the inert material in order to achieve the desirable digestible tryptophan levels. The treatments consisted of $0.209 \%$ (basal diet); $0.223 \% ; 0.235 \%$ and $0.248 \%$ digestible tryptophan for the pre-starter phase (experiment 1). For the starter phase (experiment 2), the treatments consisted of $0.187 \%$ (basal diet); $0.200 \% ; 0.211 \%$ and $0.223 \%$ digestible tryptophan.

The broilers used for the starter phase were created in the same boxes and in the same experimental shed, but during the pre-starter phase they received a diet that attended the requirements for this period, according to the recommendations of Rostagno et al. (2011), receiving the experimental diets at the next phase, and avoiding residual responses. Diets were composed of ground maize grain, soybean meal, chicken viscera/bowels meal and bone meal, meat and bone meal, supplemented with industrial amino acids L-lysine, DL-methionine, L-threonine, L-arginine, L-valine, and L-tryptophan. The percentages and nutritional composition of experimental diets of the experiments are presented in Tables 1 and 2.

Chicks received feed and water ad libitum throughout the trial period, and feeders were supplied three times a day to avoid waste. The drinkers were cleaned and water was changed daily. Temperature was monitored by thermometers and the environment was controlled with plastic curtains.

Performance variables that were evaluated were: feed intake (FI), the gain in average weight (GAW) and feed conversion (FC), and daily feed consumption per bird per day (DFC) on the first and seventh days for the pre-starter phase and on the 8th, 14th and 21st days for the starter phase.

Two metabolic assays based on a total excreta collection method were performed in the period from 3 to 7 days old (pre-starter phase) and 18 to 21 days old (starter phase). During the trial period, feed intake, total excreta produced and the chick weights were measured. Excreta was collected twice a day (8:00 and 16:00), placed in plastic bags and stored in a freezer at $-20{ }^{\circ} \mathrm{C}$. Subsequently, the samples were thawed, weighed, and homogenized, and aliquots were taken for laboratory analysis. They were predried in an air-ventilated oven at $55{ }^{\circ} \mathrm{C}$ for 72 hours and then the dry matter content (DM) and nitrogen (N) were determined, according to Silva and Queiroz (2002). We evaluated the nitrogen (NMC), the dry matter metabolizatibility coefficients (DMMC), the nitrogen balance (NB) and nitrogen retention (NR), according to Matterson et al. (1965). 
Table 1. Percentage composition and nutritional values of the experimental diets for male chickens in the pre-starter phase.

\begin{tabular}{|c|c|c|c|c|}
\hline \multirow{2}{*}{ Ingredients } & \multicolumn{4}{|c|}{ Levels of Digestible Tryptophan (\%) } \\
\hline & 0.209 & 0.223 & 0.235 & 0.248 \\
\hline Grain Maize & 61.193 & 61.193 & 61.193 & 61.193 \\
\hline Soybean Meal 45\% & 24.522 & 24.522 & 24.522 & 24.522 \\
\hline Chicken Bowels Meal & 5.000 & 5.000 & 5.000 & 5.000 \\
\hline Meat and Bone Meal 45\% & 5.000 & 5.000 & 5.000 & 5.000 \\
\hline Soybean Oil & 1.747 & 1.747 & 1.747 & 1.747 \\
\hline Limestone & 0.101 & 0.101 & 0.101 & 0.101 \\
\hline Salt & 0.314 & 0.314 & 0.314 & 0.314 \\
\hline Mineral and Vitamin Supplement ${ }^{1}$ & 0.400 & 0.400 & 0.400 & 0.400 \\
\hline DL-Methionine & 0.359 & 0.359 & 0.359 & 0.359 \\
\hline L-Lysine HCL & 0.447 & 0.447 & 0.447 & 0.447 \\
\hline L-Threonine & 0.163 & 0.163 & 0.163 & 0.163 \\
\hline L-Valine & 0.139 & 0.139 & 0.139 & 0.139 \\
\hline L-Arginine & 0.115 & 0.115 & 0.115 & 0.115 \\
\hline L-Tryptophan & 0.000 & 0.013 & 0.026 & 0.039 \\
\hline Starch & 0.500 & 0.487 & 0.474 & 0.461 \\
\hline Total & 100.000 & 100.000 & 100.000 & 100.000 \\
\hline \multicolumn{5}{|l|}{ Calculated Composition $^{2}$} \\
\hline Metabolizable Energy $\left(\mathrm{kcal} \mathrm{kg}^{-1}\right)$ & 2950 & 2950 & 2950 & 2950 \\
\hline Crude Protein $(\%)$ & 22.200 & 22.200 & 22.200 & 22.200 \\
\hline Available Phosphorus (\%) & 0.470 & 0.470 & 0.470 & 0.470 \\
\hline Calcium (\%) & 0.920 & 0.920 & 0.920 & 0.920 \\
\hline Digestible Lysine (\%) & 1.310 & 1.310 & 1.310 & 1.310 \\
\hline Digestible Methionine (\%) & 0.511 & 0.511 & 0.511 & 0.511 \\
\hline Digestible Met+Cist (\%) & 0.944 & 0.944 & 0.944 & 0.944 \\
\hline Digestible Threonine (\%) & 0.852 & 0.852 & 0.852 & 0.852 \\
\hline Digestible Tryptophan (\%) & 0.209 & 0.223 & 0.235 & 0.248 \\
\hline Digestible Valine (\%) & 1.009 & 1.009 & 1.009 & 1.009 \\
\hline Digestible Arginine (\%) & 1.415 & 1.415 & 1.415 & 1.415 \\
\hline Potassium (\%) & 0.590 & 0.590 & 0.590 & 0.590 \\
\hline Sodium $(\%)$ & 0.220 & 0.220 & 0.220 & 0.220 \\
\hline Typtophan/Lysine ratio & 16 & 17 & 18 & 19 \\
\hline
\end{tabular}

${ }^{1}$ Mineral and Vitamin Supplement for broiler, security levels per kilogram of product: 168000 IU Vitamin A (min); 40000 IU Vitamin D3 (min); 350 IU Vitamin E (min); 35 mg Vitamin K3 (min); 43 mg Vitamin B1 (min); $120 \mathrm{mg}$ Vitamin B2 (min); $62 \mathrm{mg}$ Vitamin B6 (min); 240 mg Vitamin B12 (min); 312 mg Pantothenic Acid (min); $840 \mathrm{mg}$ Niacin (min); $20 \mathrm{mg}$ Folic Acid (min); $3037 \mathrm{mg}$ Choline (min); $57 \mathrm{~g}$ Phosphorus (min/max); $57 \mathrm{mg}$; Fluor (max); $200 \mathrm{mg}$ Copper (min); $1112 \mathrm{mg}$ Iron (min); $1874 \mathrm{mg}$ Manganese (min); $18 \mathrm{mg}$ Iodine (min); $1750 \mathrm{mg}$ Zinc (min); $7 \mathrm{mg}$ Selenium (min); $226.73 \mathrm{~g}$ Calcium (min/max); $40 \mathrm{~g}$ Sodium (min/max); 25000 FYT Phytase; 1375 mg Zinc Bacitracin (min); 39 g Methionine; 1250 mg Narasin; 1250 mg Nicarbazine; 1 mg Biotin (min).

${ }^{2}$ According to Rostagno et al. (2011), except for Tryptophan. 
Table 2. Percentage composition and nutritional values of the experimental diets for male broilers in the starter phase.

\begin{tabular}{|c|c|c|c|c|}
\hline \multirow{2}{*}{ Ingredients } & \multicolumn{4}{|c|}{ Levels of Digestible Tryptophan (\%) } \\
\hline & 0.187 & 0.200 & 0.211 & 0.223 \\
\hline Grain Maize & 65.785 & 65.785 & 65.785 & 65.785 \\
\hline Soybean Meal $45 \%$ & 20.220 & 20.220 & 20.220 & 20.220 \\
\hline Chicken Bowels Meal & 5.000 & 5.000 & 5.000 & 5.000 \\
\hline Meat and Bone Meal 45\% & 5.000 & 5.000 & 5.000 & 5.000 \\
\hline Soybean Oil & 1.656 & 1.656 & 1.656 & 1.656 \\
\hline Salt & 0.293 & 0.293 & 0.293 & 0.293 \\
\hline Mineral and Vitamin Supplement ${ }^{1}$ & 0.400 & 0.400 & 0.400 & 0.400 \\
\hline DL-Methionine & 0.293 & 0.293 & 0.293 & 0.293 \\
\hline L-Lysine HCL & 0.542 & 0.542 & 0.542 & 0.542 \\
\hline L-Threonine & 0.126 & 0.126 & 0.126 & 0.126 \\
\hline L-Valine & 0.100 & 0.100 & 0.100 & 0.100 \\
\hline L-Arginine & 0.085 & 0.085 & 0.085 & 0.085 \\
\hline L-Tryptophan & 0.000 & 0.013 & 0.024 & 0.034 \\
\hline Starch & 0.500 & 0.487 & 0.476 & 0.466 \\
\hline Total & 100.000 & 100.000 & 100.000 & 100.000 \\
\hline \multicolumn{5}{|l|}{ Calculated Composition $^{2}$} \\
\hline Metabolizable Energy $\left(\mathrm{kcal} \mathrm{kg}^{-1}\right)$ & 3000 & 3000 & 3000 & 3000 \\
\hline Crude Protein (\%) & 20.800 & 20.800 & 20.800 & 20.800 \\
\hline Available Phosphorus (\%) & 0.391 & 0.391 & 0.391 & 0.391 \\
\hline Calcium (\%) & 0.819 & 0.819 & 0.819 & 0.819 \\
\hline Digestible Lysine (\%) & 1.174 & 1.174 & 1.174 & 1.174 \\
\hline Digestible Met+Cist (\%) & 0.846 & 0.846 & 0.846 & 0.846 \\
\hline Digestible Metihonine (\%) & 0.458 & 0.458 & 0.458 & 0.458 \\
\hline Digestible Threonine (\%) & 0.763 & 0.763 & 0.763 & 0.763 \\
\hline Digestible Tryptophan (\%) & 0.187 & 0.200 & 0.211 & 0.223 \\
\hline Digestible Valine (\%) & 0.904 & 0.904 & 0.904 & 0.904 \\
\hline Digestible Arginine (\%) & 1.268 & 1.268 & 1.268 & 1.268 \\
\hline Potassium (\%) & 0.585 & 0.585 & 0.585 & 0.585 \\
\hline Sodium $(\%)$ & 0.210 & 0.210 & 0.210 & 0.210 \\
\hline Tryptophan/Lysine ratio & 16 & 17 & 18 & 19 \\
\hline
\end{tabular}

${ }^{1}$ Mineral and Vitamin Supplement for broilers, security levels per kilogram of product: 168000 IU Vitamin A (min); 40000 IU Vitamin D3 (min); 350 IU Vitamin E (min); 35 mg Vitamin K3 (min); 43 mg Vitamin B1 (min); 120 mg Vitamin B2 (min); 62 mg Vitamin B6 (min); 240 mg Vitamin B12 (min); 312 mg Pantothenic Acid (min); 840 mg Niacin (min); 20 mg Folic Acid (min); $3037 \mathrm{mg}$ Choline (min); $57 \mathrm{~g}$ Phosphorus (min/max); $57 \mathrm{mg}$ Fluor (max); $200 \mathrm{mg}$ Copper (min); $1112 \mathrm{mg}$ Iron (min); $1874 \mathrm{mg}$ Manganese (min); 18 mg Iodine (min); $1750 \mathrm{mg}$ Zinc (min); $7 \mathrm{mg}$ Selenium (min); $226.73 \mathrm{~g}$ Calcium (min/max); $40 \mathrm{~g} \mathrm{Sodium}$ (min/max); 25000 FYT Phytase; 1375 mg Zinc Bacitracin (min); 39 g Methionine; 1250 mg Narasin; 1250 mg Nicarbazine; 1 mg Biotin (min).

${ }^{2}$ According to Rostagno et al. (2011), except for Tryptophan.

Performance data and metabolism of the feed nutrients were subjected to analysis of variance (ANOVA). Estimations of digestible tryptophan levels were performed using models of linear and quadratic regression at the level of up to $5 \%$ probability. SAS 9.2 software was used. 


\section{Results and Discussion}

There was no effect $(\mathrm{P}>0.05)$ of digestible tryptophan levels tested on weight gain, feed intake or feed conversion in the pre-starter phase (Table
3). Based on these results, it is suggested that the digestible tryptophan level of $0.209 \%$, a ratio tryptophan:lysine of $16 \%$, is sufficient for good performance of male chickens.

Table 3. Performance of male broilers fed with different diet levels of digestible tryptophan in the pre-starter phase (one to seven days).

\begin{tabular}{ccccccc}
\hline Tryptophan $(\%)$ & FI $(\mathbf{g})$ & SAW $(\mathbf{g})$ & FAW $(\mathbf{g})$ & AWG $(\mathbf{g})$ & FC $(\mathbf{g} / \mathbf{g})$ & DFC $(\mathbf{g})$ \\
\hline 0.209 & 115.2 & 43.4 & 159.4 & 116.0 & 0.992 & 16.40 \\
0.223 & 115.4 & 43.4 & 159.8 & 116.6 & 0.990 & 16.40 \\
0.235 & 117.8 & 44.4 & 162.0 & 117.8 & 1.002 & 16.80 \\
0.248 & 117.8 & 44.0 & 161.0 & 117.2 & 1.006 & 17.00 \\
\hline CV (\%) & 7.44 & 2.10 & 4.79 & 6.75 & 3.87 & 6.91 \\
\hline Mean & 116.6 & 43.8 & 160.5 & 116.9 & 0.99 & 16.6 \\
\hline P & 0.935 & 0.275 & 0.948 & 0.985 & 0.888 & 0.797 \\
\hline
\end{tabular}

FI: Feed Intake; SAW: Starter Average Weight; FAW: Final Average Weight; AWG: Average Weight Gain; FC: Feed Conversion; DFC: Daily Feed Consumption Per Bird Per Day.

The digestible tryptophan levels found in this study differ from the recommendations of Rostagno et al. (2011) that $0.223 \%$ digestible tryptophan is ideal for the pre-starter phase and a tryptophan:lysine ratio of $17 \%$. However, previously Rostagno et al. (2005) suggested the ratio of $16 \%$ between digestible lysine and tryptophan as ideal for this phase.

A lower value was found by Morais (2011) who recommended $0.186 \%$ as the best for this phase, meaning a tryptophan:lysine ratio of $14 \%$, which is lower than this study found. The same author reports that broilers submitted to diets with higher levels of digestible tryptophan ( 0.240 and $0.267 \%)$ had the worst performance, which means that when this amino acid excess, weight gain is negatively affected. Using semi-purified diets, for this phase, Blair et al. (2007) suggested a ratio tryptophan:lysine of $18 \%$.

There was also no effect $(\mathrm{P}>0.05)$ of digestible tryptophan levels on nitrogen balance, the metabolizability coefficients of nitrogen, or dry matter and nitrogen retention in the pre-starter phase (Table 4). Based on the results, it is suggested that the digestible tryptophan level of $0.209 \%$ ratio tryptophan:lysine of $16 \%$ is enough to improve nutrient assimilation in the first week of age. This value is slightly higher than the recommendation of Cobb's genetic line $0.18 \%$ for the period of 0 to 10 days of age (COBB-VANTRESS, 2013).

In starter phase, there was no effect $(\mathrm{P}>0.05)$ of digestible tryptophan levels on weight gain, feed intake or feed conversion (Table 5). Based on the results, it is suggested that the digestible tryptophan level of $0.187 \%$ and a ratio tryptophan: lysine of $16 \%$ is sufficient to improve the performance of male chickens.

Similarly, Baker et al. (2002), working with birds 8 to 22 day old, and fed diets with $22.5 \%$ of crude protein with the addition of LL-Glutamic acid, indicated a ratio tryptophan:lysine of $16.6 \%$. The digestible tryptophan levels found in this study differ from the level found in the studies of Rostagno et al. (2011), which suggest $0.200 \%$ digestible tryptophan for the starter phase and a tryptophan:lysine ratio of $17 \%$. 
Table 4. Metabolization coefficient of diets for male broilers fed with different levels of digestible tryptophan during the pre-starter phase (one to seven days).

\begin{tabular}{ccccc}
\hline Tryptophan (\%) & NB (g) & NMC (\%) & DMMC (\%) & NRet \\
\hline 0.209 & 26.66 & 67.14 & 75.45 & 27.91 \\
0.223 & 27.05 & 68.99 & 76.43 & 30.88 \\
0.235 & 29.47 & 69.22 & 76.33 & 29.40 \\
0.248 & 30.04 & 70.28 & 77.80 & 31.35 \\
\hline CV (\%) & 12.61 & 4.34 & 2.73 & 12.24 \\
\hline Mean & 28.05 & 68.91 & 76.50 & 29.88 \\
\hline P & 0.443 & 0.439 & 0.383 & 0.460 \\
\hline
\end{tabular}

NB: Nitrogen Balance; NMC: Nitrogen Metabolization Coefficient; DMMC: Dry Matter Metabolization Coefficient; NRet: Nitrogen Retention.

Table 5. Performance of male broilers fed with different diet levels of digestible tryptophan in the starter phase (eight to 21 days).

\begin{tabular}{ccccccc}
\hline Tryptophan $(\%)$ & FI $(\mathbf{g})$ & SAW $(\mathbf{g})$ & FAW $(\mathbf{g})$ & AWG $(\mathbf{g})$ & FC (g/g) & DFC (g) \\
\hline 0.187 & 744.8 & 130.6 & 662.2 & 531.8 & 1.406 & 53.20 \\
0.200 & 751.0 & 133.4 & 655.0 & 521.8 & 1.450 & 53.40 \\
0.211 & 767.6 & 127.6 & 674.8 & 547.6 & 1.399 & 54.80 \\
0.223 & 760.8 & 133.2 & 681.4 & 548.0 & 1.408 & 54.40 \\
\hline CV (\%) & 7.55 & 5.46 & 7.01 & 8.07 & 2.42 & 7.73 \\
\hline Mean & 756.0 & 131.2 & 668.3 & 537.3 & 1.41 & 53.9 \\
\hline P & 0.923 & 0.555 & 0.807 & 0.731 & 0.127 & 0.913 \\
\hline
\end{tabular}

FI: Feed Intake; SAW: Starter Average Weight; FAW: Final Average Weight; AWG: Average Weight Gain; FC: Feed Conversion; DFC: Daily Feed Consumption Per Bird Per Day.

For feed intake, there was no difference $(\mathrm{P}>$ 0.05), which is similar to the results obtained by Campos et al. (2012). Among other essential amino acids, tryptophan can be important because of its participation in protein synthesis, and because it is a serotonin precursor, which is related to food intake behavior (HENRY et al., 1992). But in this experiment, the ratio of $16 \%$ of lysine was enough to attend the chick's requirements.

In a study to determine the tryptophan nutritional requirements for Cobb male broilers in the starter phase (7-21 days), Campos et al. (2010) evaluated five ratios of digestible tryptophan/lysine: 15, 16, 1718 and $19 \%$, and recommended a $17 \%$ ratio, corresponding to $0.184 \%$ of digestible tryptophan.
Superior results were verified by Castro et al. (2000), who obtained, by quadratic regression, a minimum requirement for tryptophan broilers from 1 to 21 days of age of $0.212 \%$. Hsia et al. (2005) at the end of a series of experiments, found that the best performance was obtained by one whose tryptophan level was $0.198 \%$. Rosa et al. (2001) based on a review of the data of several papers, determined the tryptophan level to be $0.25 \%$ for phase 1 to 21 days of age. Levels well above that were found in this study, andthis difference may be due to the dynamic genetic improvement of strains of broiler chickens, which it had reduced its demands on the prior strains. Therefore, this justifies the need for constant work on nutritional requirements, as they vary constantly. 
Finally, there was no significant effect $(\mathrm{P}>$ 0.05) of digestible tryptophan levels of the feed on the nitrogen balance, the coefficient of nitrogen metabolization, the coefficient of dry matter metabolization or nitrogen retention capacity in the starter phase (Table 6). Based on the results, it is suggested that the digestible tryptophan level of $0.187 \%$, a tryptophan:lysine ratio of $16 \%$, is sufficient to improve the assimilation ability of nutrients provided by the diet. This value is higher the recommendation of the Cobb genetic line $0.17 \%$ for the period of 11 to 22 days of age (COBBVANTRESS, 2013).

Table 6. Metabolization coefficient of diets for male broilers fed with diets containing different levels of digestible tryptophan during the starter phase (eight to 21 days).

\begin{tabular}{ccccc}
\hline Tryptophan (\%) & NB (g) & NMC (\%) & DMMC (\%) & NRet \\
\hline 0.187 & 73.37 & 73.42 & 82.11 & 40.76 \\
0.200 & 65.02 & 70.65 & 80.94 & 38.77 \\
0.211 & 71.65 & 72.99 & 81.48 & 40.66 \\
0.223 & 71.96 & 73.34 & 81.43 & 38.82 \\
\hline CV (\%) & 11.26 & 2.41 & 1.60 & 5.07 \\
\hline Mean & 70.50 & 72.60 & 81.49 & 39.75 \\
\hline P & 0.378 & 0.074 & 0.580 & 0.255 \\
\hline
\end{tabular}

NB: Nitrogen Balance; NMC: Nitrogen Metabolization Coefficient; DMMC: Dry Matter Metabolization Coefficient; NRet: Nitrogen Retention.

\section{Conclusion}

It is possible to conclude that the basal diet with $0.209 \%$ digestible tryptophan for the prestarter phase and $0.187 \%$ for the starter phase, at a tryptophan: lysine ratio of $16 \%$, as sufficient to meet the broilers' requirements.

\section{Ethics and Biosafety Committee}

All procedures in this study were performed in accordance with Registration Protocol CEUA/UFG 063/13 by the Ethics Committee on Animal Use, the Universidade Federal de Goiás.

\section{References}

AFTAB, U.; ASHRAF, M.; JIANG, Z. Low protein diets for broilers. World's Poultry Science Journal, v. 62, n. 4, p. 688-701, 2006.
BAKER, D. H.; BATAL, A. B.; PARR, T. M.; AUGSPURGER, N. R.; PERSONS, C. M. Ideal ratio (relative to lysine) of tryptophan, threonine, isoleucine, and valine for chicks during the second and third weeks posthatch. Poultry Science, Savoy, v. 81, n. 4, p. 485-494, 2002.

BLAIR, R.; CHONG, C. H.; HOSSAIN, S. M. Growth responses of broiler to different levels of threonine and tryptophan in chemically-defined diets. The Journal of Poultry Science, v. 44, n. 3, p. 305-313, 2007.

BORGES, A. F.; OLIVEIRA, R. F. M.; DONZELE, J. L.; ALBINO, L. F. T.; ORLANDO, U. A. D.; FERREIRA, R. A. Exigência de Lisina para pintos de corte machos mantidos em ambiente com alta temperatura. Revista Brasileira de Zootecnia, Viçosa, MG, v. 31, n. 1, p. 394401, 2002.

CAMPOS, A. M. A.; NOGUEIRA, E. T.; ALBINO, L. F. T.; ROSTAGNO, H. S. Effects of digestible tryptophan:lysine ratios on performance and breast yield of broilers. In: EUROPEAN POULTRY CONFERENCE, 13., 2010, Paris. Proceedings... Paris: The World's Poultry Science Association, 2009. CDROM. 
CAMPOS, A. M. A.; ROSTAGNO, H. S.; NOGUEIRA, E. T.; ALBINO, L. F. T.; PEREIRA, J. P. L.; MAIA, R. C. Atualização da proteína ideal para frangos de corte: arginina, isoleucina, valina e triptofano. Revista Brasileira de Zootecnia, Viçosa, MG, v. 41, n. 2, p. 323332, 2012.

CASTRO, A. J.; GOMES, P. C.; PUPA, J. M. R.; ROSTAGNO, H. S.; ALBINO, L. F. T.; NASCIMENTO, A. H. Exigência de triptofano para frangos de corte de 1 a 21 dias de idade. Revista Brasileira de Zootecnia, Viçosa, MG, v. 29, n. 6, p. 1743-1749, 2000.

COBB-VANTRESS. Suplemento: desempenho e nutrição para frangos de corte Cobb500. São Paulo: COBB, 2013. Disponível em: <http://www.cobb-vantress. com/languages/guidefiles/793a16cc-5812-4030-94361e5da177064f_pt.pdf>. Acesso em: 7 fev. 2016.

CORZO, A.; DOZIER, W. A.; LOAR II, R. E.; KIDD, M. T.; TILLMAN, P. B. Dietary limitation of isoleucine and valine in diets based on maize, soybean meal, and meat and bone meal for broiler chickens. British Poultry Science, Edinburgh, v. 51, n. 4, p. 558-563, 2010.

DOZIER, W. A.; CORZO, A.; KIDD, M. T.; TILLMAN, P. B.; BRANTON, S. L. Determination of the fourth and fifth limiting amino acids in broilers fed on diets containing maize, soybean meal and poultry by-product meal from 28 to $42 \mathrm{~d}$ of age. British Poultry Science, Edinburgh, v. 52, n. 2, p. 238-244, 2011.

DUARTE, K. F.; JUNQUEIRA, O. M.; FILARDI, R. S.; SIQUEIRA, J. C.; GARCIA, E. A.; LAURENTIZ, A. C. Exigências em treonina para frangos de corte de 22 a 42 dias de idade. Revista Brasileira de Zootecnia, Viçosa, MG, v. 41, n. 1, p. 72-79, 2012.

EL-SLAMONEY, A. E.; EL-NENEY, B. A. M.; HASSAAN, S. F. Effect of photoperiod and tryptophan amino acid supplementation on pineal gland hormone melatonin) and its relation to performance in local strain. 1- Effect on laying han performance. Egypt Poultry Science, v. 30, n. 4, p. 927-960, 2010.

HENRY, Y.; SÈVE, B.; COLLÉAUX, Y.; GANJER, P.; SALIGAUT, C.; JÉGO, P. Interactive effects of dietary levels of tryptophan and protein on voluntary feed intake an growth performance in pigs, in relation to plasma free amino acids and hypothalamic serotonin. Journal of Animal Science, Champaign, v. 70, n. 6, p. 1873-1887, 1992.

HSIA, L. C.; HSU, J. H.; LIAO, C. T. The effect of varying levels of tryptophan on growth performance and carcass characteristics of growing and finishing broilers. Asian-Australian Journal Animal Science, v. 18, n. 2, p. 230-234, 2005.
KIDD, M. T.; HACKENHAAR, L. Dietary threonine for broilers: dietary interactions and feed additive supplement use. CAB reviews: perspectives in agriculture, veterinary science. Nutrition and Natural Resources, Oxford, v. 1, n. 5, p. 1-6, 2006.

MATTERSON, L. D.; POTTER, L. M.; STUTZ, M. W.; SINGSEN, E. P. The metabolizable energy of feed ingredients for chickens. Research Report, Connectcut, v. 7, n. 7, p. 3-11, 1965.

MORAIS, S. A. N. Exigências nutricionais de valina, isoleucina e triptofano digestivel para frangos de corte. 2011. Tese (Doutorado em Zootecnia) - Centro de Ciências Agrárias, Universidade Federal da Paraíba, Areia.

ROSA, A. P.; PESTI, G. M.; EDWARDS JÚNIOR, H. M.; BAKALLI, R. Tryptophan requirements of different broiler genotypes. Poultry Science, Savoy, v. 80, n. 12, p. 1718-1722, 2001.

ROSSI, L.; TIRAPEGUI, L. Implicações do sistema serotoninérgico no exercício físico. Arquivo Brasileiro de Endocrinologia e Metabologia, São Paulo, v. 48, n. 2, p. 227-233, 2004.

ROSTAGNO, H. S.; ALBINO, L. F. T.; DONZELE, J. L; GOMES, P. C.; OLIVEIRA, R. F.; LOPES, D. C.; FERREIRA, A. S.; BARRETO, S. L. T. Tabelas brasileiras para aves e suínos: composição de alimentos e exigências nutricionais. 3. ed. Viçosa, MG: UFV, Departamento de Zootecnia, 2011. 252 p.

ROSTAGNO, H. S.; TEIXEIRA, A.; DONZELE, J. L; GOMES, P. C.; OLIVEIRA, R. F.; LOPES, D. C.; FERREIRA, A. S.; BARRETO, S. L. T. Tabelas brasileiras para aves e suínos: composição de alimentos e exigências nutricionais. 2. ed. Viçosa, MG: UFV, Departamento de Zootecnia, 2005. 186 p.

SILVA, D. J.; QUEIROZ, A. C. Análises de alimentos: métodos químicos e biológicos. 3. ed. Viçosa, MG: Editora UFV, 2002. 235 p.

SILVA, M. F. R.; FARIA, D. E.; RIZZOLI, P. W.; SANTOS, A. L.; SAKAMOTO, M. I.; SOUSA, H. R. B. Desempenho e qualidade dos ovos de poedeiras comerciais alimentadas com rações contendo diferentes níveis de metionina e lisina. Revista Brasileira de Zootecnia, Viçosa, MG, v. 39, n. 10, p. 2246-2252, 2010.

SIQUEIRA, J. C.; SAKOMURA, N. K.; DORIGAM, C. P.; MENDONÇA, G. G.; COSTA, F. G. P.; FERNANDES, J. B. K.; DOURADO, L. R. B.; NASCIMENTO, D. C. N. Níveis de lisina em rações para frangos de corte determinados com base em uma abordagem econômica. Revista Brasileira de Zootecnia, Viçosa, MG, v. 40, n. 10, p. 2178-2185, 2011. 
TAKEARA, P.; TOLEDO, A. L.; GANDRA, E. R. S.; ALBUQUERQUE, R.; TRINDADE NETO, M. A. Lisina digestível para frangos de corte machos entre 12 e 22 dias de idade. Arquivo Brasileiro de Medicina Veterinária e Zootecnia, Belo Horizonte, v. 62, n. 6, p. 1455-1461, 2010.
VALÉRIO, S. R.; OLIVEIRA, R. F. M.; DONZELE, J. L.; GOMES, P. C.; APOLÔNIO, L. R.; RESENDE, W. O. Níveis de lisina digestíveis em rações, em que se manteve ou não a relação aminoacídica, para frangos de corte de 22 a 42 dias de idade, mantidos em estresse por calor. Revista Brasileira de Zootecnia, Viçosa, MG, v. 32, n. 2, p. 372-282, 2003. 